\title{
The Effect of Legal and Social Factors on the Increase of Tax Evasion - Case of Jordan
}

\author{
Dr. Hani Ali Al-Rawashdeh \\ Associate Professor \\ Dr. Ala' Mohammad Rabi \\ Assistant Professor \\ Department of Accounting \\ Faculty of Business \\ Jerash University \\ Jordan
}

\begin{abstract}
The study aimed at identifying the impact of legal and social factors on the increase of tax evasion in Jordan. The researchers have applied the descriptive approach for the theoretical framework, and the analytical approach for testing the study's hypotheses to achieve the objective of the study. A questionnaire has been developed and distributed over a random sample of the study's population composed of the sales and income tax auditors. (75) Questionnaires were distributed, (72) were retrieved and (2) were excluded; that is (93.3\%) of the distributed questionnaires. results revealed that there are a positive relationship between Legal factors (the lack of corporate governance, The lack of severity of penal system, The lack of clarity of law provisions and their gaps), and social factors (The lack of taxpayer's loyalty to the state, The unjust of tax system. The societies admirable view for evaders) and increase the cases of tax evasion. Therefore, the study recommended reviewing tax legislations, and emphasizing the commitment to corporate governance to reduce tax evasion.
\end{abstract}

Keywords: corporate governance, taxpayer loyalty, justice of tax system, tax evasion.

\section{Introduction}

The world has identified taxes since the early ages and civilizations. Countries have organized and displayed different names for taxes according to the political and religious life around the world, such as Jibayah, Zakat and others. In Jordan, like any other country, and since the foundation of the Jordanian State, the Jordanian constitution and law have legislated the processes of collecting all types of taxes. Income tax was founded in 1951, and was in force under the act No. (50) of 1950. Since then, tax legislation has undergone several amendments aimed at developing it, keeping abreast of economic and social developments, and filling gaps arising from the application (Bani Ershid, 2017).

The most recent amendment was the amended act No. (38) of 2018 applicable on 1/1/2019. Therefore, this study came to follow up the factors causing the increase in the cases of tax evasion despite the state's attempts to reduce them in every applied amendment on laws and regulations.

\section{Problem and questions of the study}

The problem of the study is represented in the following two main questions:

Q1: What is the impact of legal factors on the increase of tax evasion in Jordan? Out of this question stems the following sub-questions:

Q11: Does the lack of corporate governance help in the increase of tax evasion in Jordan?

Q12: Does the weak rigidity of the sanctions applicable to tax evaders affect the increase of evasion?

Q13: Does the lack of clarity of the provisions of Tax Law and the gaps therein affect the increase of tax evasion in Jordan?

Q2: What is the impact of social factors on the increase of tax evasion in Jordan? Out of this question stems the following sub-questions:

Q21: What is the effect of the taxpayer's weak loyalty to the state on the increase of tax evasion in Jordan?

Q22: Does the taxpayer's feeling of the unjust tax system affect the increase of tax evasion in Jordan?

Q23: What is the impact of the society's admirable view toward tax evaders on the increase of tax evasion in Jordan? 


\section{Importance of the study}

Tax revenue is one of the most important revenues of the State Treasury in Jordan. It represents a large percentage of the gross revenues of the state budget in general. In Jordan, as a country that doesn't have natural resources, tax revenues constitute an important part of the state revenues; as for Jordan, taxes are a main backbone of the State Treasury. Reports of the Finance Committee in the House of Representatives and the Ministry of Finance show that there is a huge tax evasion in Jordan, hence the importance of this research lies in explaining the causes of this tax evasion and working on finding solutions that reduce tax evasion in Jordan.

\section{Objectives of the study}

The study aims at identifying the most important factors that affect the increase in tax evasion in Jordan. The current study also aims at achieving the following goals:

1. Identify the tax system in Jordan.

2. Identify the most important amendments that took place in 2018 for act No. (34) for the year 2014.

3. Identify the most important legal and social factors that affect tax evasion, such as the corporate governance, the lack of taxpayer's loyalty, and the weak rigidity of the sanctions applicable to tax evaders ...etc.

\section{Previous studies}

\section{The study of Al-Rawashdeh \& Al-Bawab (2018) entitled: "The Effect of the corporate governance in reducing} tax evasion in Jordan".

The study aimed at identifying the impact of corporate governance on reducing tax evasion in Jordan. The study was based on the descriptive approach and the analytical approach in collecting data to answer the study's main question: is there an impact for the corporate governance on reducing tax evasion in Jordan? A questionnaire has been distributed over a random sample of the study's population composed of Jordanian Certified Public Accountants. The number of distributed and retrieved questionnaires was (120). The appropriate statistical analysis has been applied to investigate the opinions of the study's sample and to test the hypotheses. One of the most important results is that there is an impact for the corporate governance on reducing tax evasion in Jordan; this means that the principles of corporate governance shall be applied in order to reduce tax evasion. The study recommended the importance of issuing the needed legislations to apply the principles of corporate governance and conducting courses for those concerned for the justice of tax accountability under the laws in force. The most important recommendations: activate and reinforce more the role of corporate governance in the industrial sector.

2. The study of Olemat \&Isa (2016), entitled: "The Impact of Implementing the Principles of corporate Governance in Reducing Tax Evasion in Jordan: A Field Study".

The study aimed at identifying the impact of implementing the principles of corporate governance in reducing tax evasion from the perspective of the estimators of senior taxpayers sector in the sales and income tax department, taking into account that sales and income tax is one of the financial policy's tools in Jordan, and one of the revenues resources that the state depends on in drawing the financial policies. To achieve the objectives of the study and solve its problem, the researchers distributed (35) questionnaires over the tax estimators of senior taxpayer sector. (33) Valid questionnaires have been retrieved. SPSS was used to analyze the results among which was: there is an impact for the application of the corporate governance principles on reducing tax evasion. The study recommended: working on applying the principles of corporate governance in the Jordanian corporations in a way that serves in reducing tax evasion that results from the traditional means of combating tax evasion, considering the corporate governance as one of the effective means of control.

\section{What distinguishes the current study?}

Many studies handled the subject of tax evasion through several factors such as the corporate governance and some social and economic factors, whereas the current study has dealt with most of the social and legal aspects in a comprehensive manner within the limits of the researchers' knowledge of act (38) for 2018 that will be in force on $1 / 1 / 2019$.

\section{Hypotheses of the study}

Based on the literature and the problem of the study, the following hypotheses have been reached:

H01: There is no impact for the legal factors at Sig. $(\curvearrowright \leq .05)$ on the increase of tax evasion in Jordan. From this stems the following sub-hypotheses:

$\mathrm{H} 01_{1}$ : There is no a statistically significant effect at Sig. $(\gamma \leq .05)$ for the corporate governance on the increase of tax evasion in Jordan. 
$\mathrm{H} 01_{2}$ :There is no a statistically significant effect at Sig. $(\alpha \leq .05)$ for the level of rigidity of the sanctions applicable to tax evaders on the increase of tax evasion in Jordan.

$\mathrm{HO1}_{3}$ : There is no a statistically significant effect at Sig. $(\boldsymbol{\partial} \leq .05)$ for the level of clarity of the provisions of Tax Law and the gaps therein on the increaseof tax evasion in Jordan.

H02: There is no effect for the social factors at sig. $(\curvearrowright \leq .05)$ on the increase of tax evasion in Jordan. Out of this stems the following sub-hypotheses:

H021: There is no a statistically significant effect at Sig. $(\sigma \leq .05)$ for the level of the taxpayer's loyalty to the state and his feeling towards the state's right to impose taxes on the increase of tax evasion in Jordan.

H022: There is no a statistically significant effect at Sig. $(\gamma \leq .05)$ for the taxpayer's feeling of the unjust of tax system on the increase of tax evasion in Jordan.

$\mathrm{HO2}_{3}$ : There is no a statistically significant effect at Sig. $(\boldsymbol{\gamma} \leq .05)$ for the society's admirable view toward tax evaders on the increase of tax evasion in Jordan.

\section{Theoretical framework}

\section{1- Tax identification}

Tax accounting is one of the branches of accounting science, concerned with demonstrating the accounting data necessary for the purposes of determining tax profit (taxable profit) in accordance with the provisions of Tax Laws, as well as it looks into presenting and analyzing the differences between the accounting principles and the common tax provisions in order to bring a convergence of views on the disputed issues (Al-Rifai \&Al-Najdawi, 2012).

\section{2- Tax types}

Taxes are divided into two main types: direct tax and indirect tax, under each goes a number of types as explained below:

\section{First: Direct Tax}

Direct tax is the tax that the taxpayer cannot transfer its burden to another person but is borne by the taxpayer wholly and definitively. It is levied on the value of what a person earns or on the elements of capital he owns, where income tax is considered as a direct tax.

\section{Second: Indirect Tax}

Indirect tax are the tax that taxpayer can transfer to another person, usually are imposed on specific services or goods and when the final customer buys the service or the commodity, he pays this tax. Based on this, indirect taxes burden can be transferred from one person to another and ultimately borne by the consumer, such as the General Sales Tax (Bani Irshid, 2017).

\section{3-Tax system features in Jordan}

1- Direct qualitative tax of personal quality: tax on income, whether on salaries or work earnings, is qualitative and qualitative taxes are often known as taxes in kind.

2- Annualized tax: the yearly tax is one of the most important characteristics of income tax in Jordan as it is an annual tax on the income earned over the whole year.

3- Progressive Tax: tax on income is progressive in segments over individuals according to Article (11) of Act No. (28) of 2009, as the Jordanian project has divided income into segments on which it imposed tax at different rates, where the higher the income is the higher the rate becomes. (Al-Rifai \&Al-Najdawi, 2012).

\section{4-General rules of taxation}

The four rules of (justice, certainty, convenience and economical collection) are the implicit general constitution to which the tax legal rule is subject, and the state's respect for these rules reduces their intensity and makes them acceptable by individuals when the state imposes the tax.

These rules will be listed in brief as follows: (Al-Rifai \& Al-Najdawi, 2012)

1. The rule of equality and justice: it means that the nationals of the State shall contribute in its expenses according to their relative ability, i.e. the proportion of income they enjoy under the protection of the state, which is known as the principle of tax generality.

2. The rule of certainty (simplicity and clarity): it means that good tax is the one that is clearly specified for the taxpayer, unambiguous in a way that doesn't put the taxpayer under the weight of jurisprudence, the matter thatprotects him from the arbitrariness of tax administrations.

3. The rule of convenience: it means that each tax shall be collected in the most appropriate time and in the most appropriate manner for the taxpayer; that is to be collected from the taxpayer directly after he realizes his revenues or income to avoid their burden on him. 
4. The rule of economical collection: means to be economical in the cost of tax collection; in other words, tax receipts must be greater than the state's expense incurred in the process of taxation and tax collection.

5. The rule of flexibility: means to increase tax receipts according to the increase of daily income and wealth.

6. The rule of productivity: means that tax receipts shall be greatso few taxes obviate the need for plenty variant taxes.

\section{Tax evasion}

Tax evasion is when taxpayer carries out some illegal acts or business that would reduce the amount of tax due. Tax evasion is divided into two parts:

Illegal tax evasion, tax planning or tax avoidance.For tax evasion in Jordan, it has been dealt with in Article (66) of the amended act of income tax law no. (38) for the year 2018.

In Article (2) of the same act, law has considered tax evasion as the use of twisted ways based on manipulation, fraud, falsification, hiding data, or presenting fictitious data, in a purposeful manner aiming at not paying the tax, not declaring it totally or partially, or reducing it according to this act.

The Jordanian legislator imposed, through the amended law of income tax law (38) for the year 2018 (article 66 item A), a compensatory fine equals the double of the tax difference over those who evade from the tax or try to evade or help or incite others to evade the tax.

One of the illegal tax evasion forms is the manipulation of ownership of the source of income: the taxpayer may resort to nominally relinquish his source of income to a tax-exempt charity while maintaining the actual control over the source of income in order not to pay or reduce the value of the tax. The Jordanian legislator has named this type of action as the coefficient of disposition (an amended act of Income Tax Law No. (38) of 2018, Article (20)).

The most important reasons that lead to tax evasion are: (Abu Nassar, Muhammad, 2019, edition 3, p.23):

1. the extent of the taxpayer's loyalty to the state and hisfeeling towards the state's right to impose taxes: as the taxpayers' desire of not paying the tax through evasion may increase with the increase of the taxpayer's feeling that the state is not entitled to impose the tax or because he feels that tax revenues are not used for the public interest.

2. The taxpayer's feeling that tax system is unjust, as there are categories in the society that must pay taxes but they are exempt.

3. The rigidity of the penal system applied to tax evaders; whenever the penal system imposed by the applicable laws is firm on tax evaders, tax evasion tends to decrease. Penalties could be firm but inactive, therefore penal law shall be activated.

4. The society's perspective of tax evaders: societies that see evaders in an impressive manner lead to the increase of tax evasion.

5. The extent of clarity of law provisions and the gapes in them; as the ambiguity of law provisions and the loopholes in them may increase tax evasion.

\section{Statistical analysis and testing hypotheses}

\section{Research methodology:}

The study's population composed of the sales and income tax auditors in Jordan for 2019.

\section{Sample of the study:}

The sample of the current study included (70) income tax auditors in Jordan for the year 2019. A questionnaire has been distributed, (75) questionnaires were distributed, (72) questionnaires were retrieved. (2) Questionnaires were excluded for being invalid for the analysis due to mistakes in filling the questionnaire. Finally, (70) questionnaires were valid for the analysis; that is $(93.3 \%)$ of the distributed questionnaires.

\section{Tool of the study:}

The researchers used the following tool for collecting data: it is a questionnaire that measures the impact of legal and social factors in the increase of tax evasion in Jordan. The questionnaire composed of two parts; the first part was related to the demographic characteristics of the study sample, the second part covered the questions related to the hypotheses of the study with (25) items distributed over six domains as follows: 
Table (1) domains of the study tool

\begin{tabular}{lll}
\hline No. & Domains & Number of items \\
\hline 1 & Legal factors & 5 \\
\hline 2 & corporate governance & 4 \\
\hline 3 & The lack of severity of penal system & 4 \\
\hline & The lack of clarity of law provisions and their gaps & \\
\hline 4 & Social factors & 4 \\
\hline 5 & The lack of taxpayer's loyalty to the state & 4 \\
\hline 6 & The unjust of tax system & 4 \\
\hline Total & The societies admirable view for evaders & 25 \\
\hline
\end{tabular}

\section{Validity of the tool:}

The scale has been reviewed by a number of attributers of the faculty members at the public and private universities in the faculties of economy and related businesses, to evaluate whether the scale's items are clear and understandable in their structure and meaning, their preparation, and whether the scales parts are clear and fit the auditors. After taking the attributors' opinion into account, some items were amended and others were deleted so the tool at the end was composed of (25) items distributed over (6) domains. With this the tool is valid to be applied on the study sample.

The researchers have calculated the correlation coefficients of the study tool and its domains to make sure that they belong to the domain and the tool as a whole. The following table shows this:

Table (2) correlation coefficients of the items with the domain and the tool as a whole (corporate governance)

\begin{tabular}{llllll}
\hline Domain & Item no. & $\begin{array}{l}\text { Correlation coefficient } \\
\text { the domain }\end{array}$ & $\begin{array}{l}\text { with } \\
\text { tool }\end{array}$ & Correlation coefficient with the \\
\hline \multirow{3}{*}{ corporate governance } & 1 & $0.602^{* *}$ & $0.334^{* *}$ & \\
\cline { 2 - 5 } & 2 & $0.689^{* *}$ & $0.236^{*}$ \\
\cline { 2 - 5 } & $0.678^{* *}$ & 0.166 \\
\cline { 2 - 5 } & $0.778^{* *}$ & $0.376^{* *}$ \\
\hline
\end{tabular}

Correlation coefficient of $0.536^{* *}$

the domain with the tool

The table shows that the correlation coefficients between the items of the domain of corporate governance and the domain itself ranged between $(0.602-0.778)$, and with the total score of the tool ranged between $(0.166-0.658)$. All were statistically significant at sig. $(\alpha=0.01)$,except for item number (2) where they were statistically significant at $(\alpha=0.05)$, and item number (3) that was not statistically significant with the tool as a whole. The correlation coefficient of the domain with the total score of the tool was (0.536) and it was statistically significant at $(\alpha=0.01)$.

Table (3) correlation coefficients of the items with the domain and the tool as a whole (the lack of severity of penal system)

\begin{tabular}{|c|c|c|c|}
\hline Domain & Item no. & $\begin{array}{l}\text { Correlation coefficient with } \\
\text { the domain }\end{array}$ & $\begin{array}{l}\text { Correlation coefficient with the } \\
\text { tool }\end{array}$ \\
\hline \multirow{4}{*}{$\begin{array}{l}\text { the lack of severity of } \\
\text { penal system }\end{array}$} & 1 & $0.769 * *$ & $0.486^{* *}$ \\
\hline & 2 & $0.812 * *$ & $0.423 * *$ \\
\hline & 3 & $0.731 * *$ & $0.324 * *$ \\
\hline & 4 & $0.701 * *$ & $0.332 * *$ \\
\hline $\begin{array}{l}\text { Correlation coefficient of } \\
\text { the domain with the scale }\end{array}$ & $0.529 * *$ & & \\
\hline
\end{tabular}

The table shows that the correlation coefficients between the items of the domain of the lack of severity of penal system and the domain itself ranged between $(0.701-0.812)$, and with the total score of the tool ranged between $(0.324-$ $0.486)$. All were statistically significant at sig. $(\alpha=0.01)$. The correlation coefficient of the domain with the total score of the tool was (0.529) and it was statistically significant at $(\alpha=0.01)$. 
Table (4) correlation coefficients of the items with the domain and the tool as a whole (the lack of clarity of law provisions and their gaps)

\begin{tabular}{lllll}
\hline Domain & Item no. & $\begin{array}{l}\text { Correlation coefficient } \\
\text { the domain }\end{array}$ & $\begin{array}{l}\text { with } \\
\text { Correlation coefficient with the } \\
\text { tool }\end{array}$ & \\
\hline \multirow{3}{*}{$\begin{array}{l}\text { the lack of clarity of law } \\
\text { provisions and their gaps }\end{array}$} & 1 & $0.804^{* *}$ & $0.586^{* *}$ & \\
\cline { 2 - 5 } & 2 & $0.877^{* *}$ & $0.726^{* *}$ & \\
\cline { 2 - 5 } & 4 & $0.910^{* *}$ & $0.587^{* *}$ \\
\hline Correlation coefficient of & $0.744^{* *}$ & $0.869^{* *}$ & $0.690^{* *}$ &
\end{tabular}

Correlation coefficient of $0.744 * *$

the domain with the scale

The table shows that the correlation coefficients between the items of the domain of the lack of clarity of law provisions and their gaps and the domain itself ranged between $(0.804-0.910)$, and with the total score of the tool ranged between $(0.586-0.726)$. All were statistically significant at sig. $(\alpha=0.01)$. The correlation coefficient of the domain with the total score of the tool was $(0.744)$ and it was statistically significant at $(\alpha=0.01)$. From the previous tables we find that all the tool's items do highly belong to the domain from which they were derived and to the tool as a whole, this proves the validity of the internal consistency of the study's tool, except for a number of items that were not significant in their correlation with the total score of the tool, but they were kept for a number of reasons among which are: their high correlation coefficients with the sub-domain to which they belong, moreover; the high correlation coefficients of the totals of sub-domains with the tool as a whole. The researchers have verified that the items that were not significant are items belonging to the domain of the study and cannot be canceled due to their practical significance in the tool.

Table (5) correlation coefficients of the items with the domain and the tool as a whole (the taxpayer's loyalty to the state)

\begin{tabular}{lllll}
\hline Domain & Item no. & $\begin{array}{l}\text { Correlation coefficient } \\
\text { the domain }\end{array}$ & $\begin{array}{l}\text { with } \\
\begin{array}{l}\text { Correlation coefficient with the } \\
\text { tool }\end{array}\end{array}$ \\
\hline \multirow{3}{*}{$\begin{array}{l}\text { the taxpayer's loyalty to to } \\
\text { the state }\end{array}$} & 1 & $0.634^{* *}$ & $0.475^{* *}$ \\
\cline { 2 - 5 } & 2 & $0.727^{* *}$ & $0.333^{* *}$ \\
\hline
\end{tabular}

Correlation coefficient of $0.652 * *$

the domain with the tool

The table shows that the correlation coefficients between the items of the domain of the taxpayer's loyalty to the state and the domain itself ranged between $(0.634-0.791)$, and with the total score of the tool ranged between $(0.333-$ $0.545)$. All were statistically significant at sig. $(\alpha=0.01)$. The correlation coefficient of the domain with the total score of the tool was (0.652) and it was statistically significant at $(\alpha=0.01)$.

Table (6) correlation coefficients of the items with the domain and the tool as a whole (the unjust of tax system)

\begin{tabular}{llll}
\hline Domain & Item no. & $\begin{array}{l}\text { Correlation coefficient } \begin{array}{l}\text { with } \\
\text { the domain }\end{array} \\
\text { the unjust of tax system }\end{array}$ & $\begin{array}{l}\text { Correlation coefficient with the } \\
\text { tool }\end{array}$ \\
\hline & 1 & $0.591^{* *}$ & $0.480^{* *}$ \\
\cline { 2 - 4 } & 2 & $0.669^{* *}$ & 0.181 \\
\cline { 2 - 4 } & 3 & $0.790^{* *}$ & $0.578^{* *}$ \\
\hline $\begin{array}{l}\text { Correlation coefficient } \\
\text { of the domain with the } \\
\text { tool }\end{array}$ & $0.599^{* *}$ & $0.822^{* *}$ & $0.524^{* *}$ \\
\hline
\end{tabular}

The table shows that the correlation coefficients between the items of the domain of the unjust of tax system and the domain itself ranged between $(0.591-0.822)$, and with the total score of the tool ranged between $(0.181-0.578)$. All were statistically significant at sig. $(\alpha=0.01)$, except for item number (2) that was not significant with the tool as a whole. The correlation coefficient of the domain with the total score of the tool was (0.599) and it was statistically significant at $(\alpha=0.01)$. 
Table (7) correlation coefficients of the items with the domain and the tool as a whole (the society's admirable view towards evaders)

\begin{tabular}{|c|c|c|c|}
\hline Domain & Item no. & $\begin{array}{l}\text { Correlation coefficient with } \\
\text { the domain }\end{array}$ & $\begin{array}{l}\text { Correlation coefficient with the } \\
\text { tool }\end{array}$ \\
\hline \multirow{4}{*}{$\begin{array}{l}\text { the society's admirable } \\
\text { view towards evaders }\end{array}$} & 1 & $0.913 * *$ & $0.788^{* *}$ \\
\hline & 2 & $0.927 * *$ & $0.810 * *$ \\
\hline & 3 & $0.870 * *$ & $0.785^{* *}$ \\
\hline & 4 & $0.581 * *$ & $0.298^{*}$ \\
\hline
\end{tabular}

Correlation coefficient of $0.822 * *$

the domain with the scale

The table shows that the correlation coefficients between the items of the domain of the society's admirable view towards evader sand the domain itself ranged between $(0.581-0.927)$, and with the total score of the tool ranged between $(0.298-0.810)$. All were statistically significant at sig. $(\alpha=0.01)$, except for item number (4) that was statistically significant at sig. $(\alpha=0.05)$ with the tool as a whole. The correlation coefficient of the domain with the total score of the tool was (0.822) and it was statistically significant at $(\alpha=0.01)$.

\section{Reliability of the scale}

The researchers have estimated the reliability coefficient of the items composing the current tool of the current sample composed of (70) auditor, Cronbach's Alpha coefficient value was (0.916), they also estimated the reliability coefficient applying the split half reliability approach and was corrected through Spearman Brown Formula, the value of the correlation coefficient between the two splits was (0.682) before the correction and (0.811)after the correction. The researchers also calculated the reliability coefficients of the domains of the study tool, the results were as follows:

Table (8) reliability coefficients of the domains of the study tool

\begin{tabular}{lll}
\hline Number & Domains & $\begin{array}{l}\text { Value of reliability } \\
\text { coefficient }\end{array}$ \\
\hline 1 & The weak commitment to corporate governance & 0.714 \\
\hline 2 & The lack of rigidity of the penal system & 0.728 \\
\hline 3 & The lack of clarity of law provisions and the gape in them & 0.886 \\
\hline 4 & The lack of the taxpayer's loyalty to the state & 0.705 \\
\hline 6 & The unjust of tax system & 0.689 \\
\hline
\end{tabular}

The table shows that all reliability coefficients of the study tool's domains were within the acceptable range for this type of humanitarian studies as the values ranged between $(0.419-0.886)$.

\section{Statistical approaches}

1. Pearson correlation coefficient to calculate the internal consistency of the study tools.

2. Cronbach's Alpha and (split - half) coefficient to calculate reliability coefficient of the study tool areas.

3. One way ANOVA

4. Arithmetic means, standard deviations and repetitions.

5. Eta squared to measure the effect.

Table (9) Criterion of grading interpretation of the study tool items

\begin{tabular}{ll}
\hline Grade range & Grade interpretation \\
\hline $1-1.8$ & Very low \\
\hline $1.81-2.6$ & Low \\
\hline $2.61-3.4$ & Medium \\
\hline $3.41-4.2$ & High \\
\hline $4.21-5$ & Very high \\
\hline
\end{tabular}

\section{Sample selection}

The researchers have selected the sample of the study following the simple random sample method; auditors have been selected in their work places in three governorates (Irbid, Amman and Zarqa).

Demographic characteristics of the study sample 
The study sample included sales and income tax auditors, distributed according to the demographic variables of the study (academic qualification, experience, and specialty). This can be shown in the following table:

\section{Academic qualification}

Table (10) distribution of the study sample according to the variable of academic qualificationN=70

\begin{tabular}{lll}
\hline Academic qualification & Repetitions & Percentage \\
\hline Less than a Bachelor & 0 & $0.0 \%$ \\
\hline Bachelor & 56 & $80 \%$ \\
\hline Master & 12 & $17.1 \%$ \\
\hline PhD & 2 & $2.9 \%$ \\
\hline Total & 70 & $100 \%$ \\
\hline
\end{tabular}

The table shows the distribution of the study sample's members according to the variable of the academic qualification; (56) auditors had a Bachelor degree with a percentage of (80\%), (12) auditors had a master degree with a percentage of (17.1\%), (2) auditors had a PhD degree with a percentage of $(2.9 \%)$, and no auditor had an academic qualification that is less than a bachelor.This shows that the sample members are able to understand and answer the items of the study tool in a correct and reasonable manner.

\section{Experience}

Table (11) distribution of the study sample according to the variable of experience $\mathrm{N}=70$

\begin{tabular}{lll}
\hline Years of experience & Repetitions & Percentage \\
\hline 5 years or less & 6 & $8.57 \%$ \\
\hline $6-10$ years & 0 & $0 \%$ \\
\hline $11-15$ years & 20 & $28.57 \%$ \\
\hline 16 years or more & 44 & $62.86 \%$ \\
\hline Total & 70 & $100 \%$ \\
\hline
\end{tabular}

The table shows the distribution of the study sample's members according to the variable of experience; (6) auditors had an experience of less than (5) years with a percentage of (8.57\%), (20) auditors had an experience of (11-15 years) with a percentage of (28.57\%), and (44) auditors had and experience of (more than 16 years) with a percentage of $(62.86 \%)$. This statistic shows that all the sample members enjoy the needed knowledge and ability to answer the items of the study tool.

\section{Specialty}

Table (12) distribution of the study sample according to the variable of specialty $N=70$

\begin{tabular}{lll}
\hline Specialty & Repetitions & Percentage \\
\hline Accounting & 56 & $80.0 \%$ \\
\hline Business management & 4 & $5.7 \%$ \\
\hline Financial and Banking science & 4 & $5.7 \%$ \\
\hline Economy & 2 & $2.9 \%$ \\
\hline Others & 4 & $5.7 \%$ \\
\hline Total & 70 & $100.0 \%$ \\
\hline
\end{tabular}

The table shows the distribution of study sample's members according to the variable of specialty; (65) auditors were specialized in accounting with a percentage of $(80 \%)$, (4) auditors were specialized in business management with a percentage of $(5.7 \%)$, (4) auditors were specialized in banking and financial science with a percentage of (5.7\%), (2) auditors were specialized in economy with a percentage of (2.9\%), and (4) auditors were specialized in other specialties other than the ones mentioned here with a percentage of (5.7\%). This statistic shows that all members of the sample have the knowledge and the ability to answer the items of the study.

\section{Statistical analysis and testing hypotheses}

ANOVA test has been used to test the hypotheses of the study as follows:

The first main hypothesis H01: there is no a statistically significant effect at sig. ( $\alpha \geq 0.05)$ for the legal factors on the increase of tax evasion in Jordan.

To test this hypothesis, three hypotheses were derived from it:

The first sub-hypothesis: There is no a statistically significant effect at Sig. $(\alpha \geq 0.05)$ for the lack of corporate governance on the increase of tax evasion in Jordan. 
Table (13) ANOVA test for the domain of corporate governance $(\mathrm{N}=70)$

\begin{tabular}{lrrllll}
\hline Variance source & Squares total & DF & Squares mean & F value & Sig. \\
\hline Among groups & 6517.669 & 8 & 814.709 & & \\
\cline { 1 - 4 } Within the groups & 8197.417 & 61 & 134.384 & & \\
\cline { 1 - 4 } Total & 14715.086 & 69 & & & \\
\hline
\end{tabular}

The table shows that there is a statistically significant effect for the lack of corporate governance on the increase of tax evasion in Jordan at sig. ( $\alpha \geq 0.05)$, where the calculated (F) value was (6.063) and it is higher than the tabulated (F) value at DF of (8/61) which was according to the statistical tables (2.10). Moreover, the researchers have calculated the Practical Significance by calculating eta squared $\left(n^{2}\right)$ through the following formula:

Then, calculating the effect value (f) through the following formula:

Based on this, the calculated (f) value is (0.89); this result according to Cohen criteria is interpreted as big. As the effect size is considered small when $(0 \leq f \leq 0.24)$, medium when $(0.25 \leq f \leq 0.39)$, and big when $(0.40 \leq f \leq 1)(\mathrm{Al}-$ Sharifen, 2017). The researchers have also calculated the arithmetic means and standard deviations of the items of the domain of the lack of corporate governance to identify the level of its effect on the increase of tax evasion rates in Jordan. The results were as follows:

Table (14) arithmetic means and standard deviations of the domain of corporate governance

\begin{tabular}{llll}
\hline Item & \multicolumn{1}{c}{$\begin{array}{c}\text { Arithmetic } \\
\text { mean }\end{array}$} & $\begin{array}{l}\text { Standard } \\
\text { deviation }\end{array}$ & $\begin{array}{l}\text { Degree } \\
\text { interpretation }\end{array}$ \\
\hline $\begin{array}{l}\text { The failure to disclose international accounting information } \\
\text { increases tax evasion }\end{array}$ & 4.25 & 0.60 & Very high \\
\hline $\begin{array}{l}\text { The lack of an effective and efficient structure helps to increase } \\
\text { corporate tax evasion }\end{array}$ & 4.20 & 0.58 & High \\
$\begin{array}{l}\text { Failure to disclose the Company's objectives in the annual reports, } \\
\text { the significant risks and the shareholders' rights increases tax } \\
\text { evasion }\end{array}$ & High \\
$\begin{array}{l}\text { The shareholders non-participationto take effective and important } \\
\text { decisions related to the fundamental changes in the company helps } \\
\text { to increase the cases of tax evasion }\end{array}$ & High \\
\hline $\begin{array}{l}\text { Not respecting the rights of stakeholders in accordance with the rules } \\
\text { of corporate governance contributes to the increase of tax evasion }\end{array}$ & 3.77 & .747 & High \\
\hline \begin{tabular}{l} 
Total \\
\hline
\end{tabular}
\end{tabular}

The previous table shows that "The failure to disclose international accounting information"has a very high impact on the increase of tax evasion in Jordan for the domain of corporate governance, as this item had the highest arithmetic mean of (4.25) and a standard deviation of (0.60), whereas the rest of the items were of high effect on the increase of tax evasion in Jordan with an arithmetic means ranging between $(3.77-4.20)$.

The second sub-hypothesis: There is no a statistically significant effect at Sig. $(\alpha \geq 0.05)$ for the level of rigidity of the penal system applicable in income tax law on the increase of tax evasion in Jordan.

To test this hypothesis, the researchers applied one-way ANOVA test, the following table shows this:

Table 15 ANOVA test for the domain of the lack of rigidity of penal system applied in income tax law $(\mathrm{N}=70)$

\begin{tabular}{lcclll}
\hline Variance source & Squares total & DF & Squares mean & F value & Sig. \\
\hline Among groups & 6086.63 & 8 & 760.829 & & \\
\cline { 1 - 4 } Within the groups & 8628.455 & 61 & 141.450 & & \\
\cline { 1 - 5 } Total & 14715.086 & 69 & & \multirow{2}{*}{0.000} \\
\hline
\end{tabular}

The table shows that there is a statistically significant effect for the lack of rigidity of penal system applied in income tax law on the increase of tax evasion in Jordan at sig. ( $\alpha \geq 0.05)$, where the calculated (F) value was (5.379) and it is higher than the tabulated (F) value at DF of (8/61) which was according to the statistical tables (2.10). 
Moreover, the researchers have calculated the Practical Significance by calculating eta squared $\left(\mathrm{n}^{2}\right)$ and the effect value (f) which was (0.83), this result according to Cohen criteria is considered as high. The researchers have also calculated the arithmetic means and standard deviations of the items of the domain of the lack of rigidity of penal system applied in income tax law to identify the level of its effect on the increase of tax evasion rates in Jordan. The results were as follows:

Table (16) arithmetic means and standard deviations for the domain of the lack of rigidity of penal system applied in income tax law

\begin{tabular}{llll}
\hline Item & $\begin{array}{l}\text { Arithmetic } \\
\text { mean }\end{array}$ & $\begin{array}{l}\text { Standard } \\
\text { deviation }\end{array}$ & $\begin{array}{l}\text { Degree } \\
\text { interpre } \\
\text { tation }\end{array}$ \\
\hline $\begin{array}{l}\text { The weak penalty regarding fines imposed on evaders helps to } \\
\text { reinforce tax evasion cases. }\end{array}$ & 4.17 & 0.85 & high \\
\hline $\begin{array}{l}\text { Replacing prison sentences and arrests with money and fines makes } \\
\text { evaders careless, the matter that increases tax evasion. }\end{array}$ & 3.97 & 0.70 & High \\
\hline $\begin{array}{l}\text { Evaders balance between the benefit (saving) they gain from } \\
\text { evasion and the penalties. If this achieves a sort of saving, it would } \\
\text { encourage tax evasion. }\end{array}$ & & 0.70 & High \\
\hline Deactivating the penal system of tax evasion increases tax evasion & 4.17 & 0.44 & High \\
\hline Total & 4.07 & 0.67 & High \\
\hline
\end{tabular}

The previous table shows that "The weak penalty regarding fines imposed on evaders helps to reinforce tax evasion cases" and "Deactivating the penal system of tax evasion increases tax evasion" have a high impact on the increase of tax evasion in Jordan for the domain of the lack of rigidity of penal system applied in income tax law, as these items had the highest arithmetic mean of (4.17) and a standard deviation of (0.44), whereas the rest of the items were also of high effect on the increase of tax evasion in Jordan with an arithmetic mean of (3.97) and a high total of (4.07).

The third sub-hypothesis: There is no a statistically significant effect at Sig. ( $\alpha \geq 0.05)$ for the lack of clarity of the provisions of Tax Law and the gaps therein on the increase of tax evasion in Jordan. To test this hypothesis, the researchers applied one-way ANOVA test, the following table shows this:

Table (17) ANOVA test for the domain of the lack of clarity of law provisions and the gaps therein (N=70)

\begin{tabular}{llllll}
\hline Variance source & Squares sum & DF & Squares mean & F value & Sig. \\
\hline Among groups & 5652.686 & 12 & 471.057 & & \\
\cline { 1 - 5 } Within the groups & 9062.400 & 57 & 158.989 & \multirow{2}{*}{2.96} & \multirow{2}{*}{0.000} \\
\cline { 1 - 4 } Total & 14715.086 & 69 & & & \\
\hline
\end{tabular}

The table shows that there is a statistically significant effect for the lack of rigidity of penal system applied in income tax law on the increase of tax evasion in Jordan at sig. ( $\alpha \geq 0.05)$, where the calculated (F) value was (2.96) and it is higher than the tabulated (F) value at DF of (12/57) which was according to the statistical tables (1.92). Moreover, the researchers have calculated the Practical Significance by calculating eta squared $\left(\mathrm{n}^{2}\right)$ and the effect value (f) which was (0.79), this result according to Cohen criteria is considered as high. The researchers have also calculated the arithmetic means and standard deviations of the items of the domain of the weak prevailing economic situation in Jordan to identify the level of its effect on the increase of tax evasion rates in Jordan. The results were as follows: 
Table (18) arithmetic means and standard deviations for the domain of the lack of clarity of law regulation and the gaps therein

\begin{tabular}{llll}
\hline Item & $\begin{array}{l}\text { Arithmetic } \\
\text { mean }\end{array}$ & $\begin{array}{l}\text { Standard } \\
\text { deviation }\end{array}$ & $\begin{array}{l}\text { Degree } \\
\text { interpretation }\end{array}$ \\
\hline $\begin{array}{l}\text { The lack of clarity of a law text and the possibility of interpreting } \\
\text { the text in several interpretations encourage the increase of tax }\end{array}$ & 3.71 & 0.91 & High \\
evasion cases. & & & \\
\hline $\begin{array}{l}\text { Instructions emanating from laws that are interpreted differently } \\
\text { from one employee to another help to increase tax evasion cases }\end{array}$ & 3.91 & 0.84 & High \\
\hline $\begin{array}{l}\text { The inability of tax employee to take a decision regarding a } \\
\text { taxpayer du to not understanding the law text leads to increase tax } \\
\text { evasion. }\end{array}$ & & \\
\hline $\begin{array}{l}\text { Taxpayers hanging on to some interpretations that are in heir favor } \\
\text { as a result of the unclear law texts, instructions and tax } \\
\text { employees'wrong decisions for previous periods help in increasing } \\
\text { cases of tax evasion. }\end{array}$ & & \\
\hline Total & 3.02 & 0.96 & High \\
\hline
\end{tabular}

The previous table shows that "Instructions emanating from laws that are interpreted differently from one employee to another help to increase tax evasion cases" has a high impact on the increase of tax evasion in Jordan for the domain of the lack of clarity of law provisions and the gaps therein, as this item had the highest arithmetic mean of (3.91) and a standard deviation of (0.84), whereas the rest of the items were also of high effect on the increase of tax evasion in Jordan with an arithmetic means ranging between $(3.62-3.71)$ and with a high total of (3.70).

Testing the first main hypothesis H01: there is no a statistically significant effect at sig. ( $\alpha \geq 0.05)$ for the legal factors on the increase of tax evasion in Jordan

To test this hypothesis and identify the value of the effect resulted from previously tested factors on the increase of tax evasion in Jordan; the researchers have calculated the arithmetic means and standard deviations for each domain of the study tool domains and for the tool as a whole. The results were as follows:

Table (19) arithmetic means and standard deviations for the study tool domains and the tool as a whole (N=70)

\begin{tabular}{llll}
\hline Domain & $\begin{array}{l}\text { Arithmetic } \\
\text { mean }\end{array}$ & $\begin{array}{l}\text { Standard } \\
\text { deviation }\end{array}$ & $\begin{array}{l}\text { Result } \\
\text { interpretation }\end{array}$ \\
\hline corporate governance & 3.96 & 0.65 & High \\
\hline The lack of rigidity of penal system & 4.07 & 0.67 & High \\
\hline The lack of clarity of law provisions and the gaps therein & 3.70 & 0.96 & High \\
\hline Total sum of the tool & 3.91 & 0.76 & High \\
\hline
\end{tabular}

From the previous table we see that the increase in the lack of rigidity of penal system has had the highest arithmetic mean of (4.07) and a standard deviation of (0.67) for affecting the increase of tax evasion in Jordan. We also notice that all legal factors that have been mentioned affect the increase of tax evasion in Jordan on high estimations and high general mean.

The second main hypothesis H02: There is no a statistically significant effect for the social factors at sig. $(\alpha \geq 0.05)$ on the increase of tax evasion in Jordan. To test this hypothesis, three sub-hypotheses have been derived from it a follows: The first sub-hypothesis: There is no a statistically significant effect at Sig. $(\alpha \geq 0.05)$ for the lack of the taxpayer's loyalty to the state on the increase of tax evasion in Jordan.

To test this hypothesis, the researchers applied ANOVA analysis, the following table shows this:

Table (20) ANOVA test for the domain of the lack of the taxpayer's loyalty (N=70)

\begin{tabular}{lrrllll}
\hline Variance source & Squares sum & DF & Squares mean & F value & Sig. \\
\cline { 1 - 4 } Among groups & 6715.908 & 6 & 1119.318 & & \\
\cline { 1 - 5 } Within the groups & 7999.178 & 63 & 126.971 & & \\
\cline { 1 - 5 } Total & 14715.086 & 69 & & & \\
\hline
\end{tabular}

The table shows that there is a statistically significant effect for the lack of the taxpayer's loyalty on the increase of tax evasion in Jordan at sig. ( $\alpha \geq 0.05)$, where the calculated (F) value was (8.816) and it is higher than the tabulated (F) 
value at DF of (6/63) which was according to the statistical tables (2.25). Moreover, the researchers have calculated the Practical Significance by calculating eta squared $\left(\mathrm{n}^{2}\right)$ and the effect value (f) which was $(0.91)$, this result according to Cohen criteria is considered as high. The researchers have also calculated the arithmetic means and standard deviations of the items of the domain of the lack of taxpayer's loyalty to identify the level of its effect on the increase of tax evasion rates in Jordan. The results were as follows:

Table (21) arithmetic means and standard deviations for the domain of the lack of the taxpayer's loyalty

\begin{tabular}{llll}
\hline Item & $\begin{array}{l}\text { Arithmetic } \\
\text { mean }\end{array}$ & $\begin{array}{l}\text { Standard } \\
\text { deviation }\end{array}$ & $\begin{array}{l}\text { Degree } \\
\text { interpret } \\
\text { ation }\end{array}$ \\
\hline $\begin{array}{l}\text { The lack of loyalty of the citizen or taxpayer for the state } \\
\text { helps to increase tax evasion cases }\end{array}$ & 4.48 & 0.55 & Very high \\
\hline $\begin{array}{l}\text { The citizen's frustration towards the deterioration of } \\
\text { government services makes him evade the tax }\end{array}$ & 4.65 & 0.53 & Very high \\
$\begin{array}{l}\text { The taxpayer's comparison between the services offered to } \\
\text { him and the ones offered to taxpayers in other countries } \\
\text { makes him evade taxes }\end{array}$ & & 0.54 & Very high \\
\hline $\begin{array}{l}\text { The taxpayer's feeling that the state has no right to impose } \\
\text { taxes increases tax evasion }\end{array}$ & 4.20 & .750 & High \\
\hline Total & 4.49 & 0.59 & Very high \\
\hline
\end{tabular}

The previous table shows that "The citizen's frustration towards the deterioration of government services makes him evade the tax" has a very high impact on the increase of tax evasion in Jordan for the domain of the lack of taxpayer's loyalty for the state, as this item has had the highest arithmetic mean of (4.65) and a standard deviation of (0.53), the same as the rest of the items that were of a very high effect on the increase of tax evasion in Jordan with arithmetic means ranging between $(4.48-4.62)$, except for the item stating "The taxpayer's feeling that the state has no right to impose taxes increases tax evasion" that had an arithmetic mean of (4.20).

The second sub-hypothesis: There is no a statistically significant effect at Sig. $(\alpha \geq 0.05)$ for the taxpayer's feeling of the unjust of tax system on the increase of tax evasion in Jordan. To test this hypothesis, the researchers applied ANOVA analysis, the following table shows this:

Table (22) ANOVA test for the domain of the taxpayer's feeling of the unjust of tax system (N=70)

\begin{tabular}{|c|c|c|c|c|c|c|}
\hline Variance source & Squares sum & DF & $\begin{array}{l}\text { Squares } \\
\text { mean }\end{array}$ & F value & & Sig. \\
\hline Among groups & 5986.371 & 8 & 748.296 & & \multirow{3}{*}{5.229} & \multirow{3}{*}{.000} \\
\hline $\begin{array}{l}\text { Within the } \\
\text { groups }\end{array}$ & 8728.714 & 61 & 143.094 & & & \\
\hline Total & 14715.086 & 69 & & & & \\
\hline
\end{tabular}

The table shows that there is a statistically significant effect for the taxpayer's feeling of the unjust of tax system on the increase of tax evasion in Jordan at sig. $(\alpha \geq 0.05)$, where the calculated (F) value was (5.229) and it is higher than the tabulated (F) value at DF of (8/61) which was according to the statistical tables (2.10). Moreover, the researchers have calculated the Practical Significance by calculating eta squared $\left(\mathrm{n}^{2}\right)$ and the effect value (f) which was $(0.82)$, this result according to Cohen criteria is considered as high. The researchers have also calculated the arithmetic means and standard deviations of the items of the domain of the taxpayer's feeling of the unjust of tax system to identify the level of its effect on the increase of tax evasion rates in Jordan. The results were as follows: 
Table (23) arithmetic means and standard deviations for the domain of the taxpayer's feeling of the unjust of tax system

\begin{tabular}{llll}
\hline Item & $\begin{array}{l}\text { Arithmetic } \\
\text { mean }\end{array}$ & $\begin{array}{l}\text { Standard } \\
\text { deviation }\end{array}$ & $\begin{array}{l}\text { Degree } \\
\text { interpreta } \\
\text { tion }\end{array}$ \\
\hline $\begin{array}{l}\text { The taxpayer's feeling of the inequality and unfairness in the } \\
\text { distribution of tax proportions helps promote tax evasion }\end{array}$ & 4.48 & 0.50 & Very high \\
\hline $\begin{array}{l}\text { There are categories of the society who are solely responsible } \\
\text { for paying the tax }\end{array}$ & 4.08 & 0.84 & High \\
\hline $\begin{array}{l}\text { There are categories of the society that are exempt from tax } \\
\text { in return for a donation to the State that does not match the } \\
\text { amount of tax due. This irritates the taxpayers and increases } \\
\text { tax evasion }\end{array}$ & 0.91 & High \\
\hline $\begin{array}{l}\text { Exemption of certain categories of the society from tax } \\
\text { exclusively increases tax evasion }\end{array}$ & & & \\
\hline Total & 3.77 & 0.90 & High \\
\hline
\end{tabular}

The previous table shows that "The taxpayer's feeling of the inequality and unfairness in the distribution of tax proportions helps promote tax evasion" has a very high impact on the increase of tax evasion in Jordan for the domain of the taxpayer's feeling of the unjust of tax system, as this item had the highest arithmetic mean of (4.48) and a standard deviation of (0.50). The rest of the items had a high effect on the increase of tax evasion in Jordan with arithmetic means ranging between $(3.48-4.08)$, and a high total as well with an arithmetic mean of (3.95). The third sub-hypothesis: There is no a statistically significant effect at Sig. $(\alpha \geq 0.05)$ for the society's admirable view toward tax evaders on the increase of tax evasion in Jordan. To test this hypothesis, the researchers applied ANOVA analysis, the following table shows this:

Table (24) ANOVA test for the domain of the society's admirable view toward tax evaders $(\mathrm{N}=70)$

\begin{tabular}{|c|c|c|c|c|c|}
\hline Variance source & Squares sum & $\mathrm{DF}$ & Squares mean & F value & Sig. \\
\hline Among groups & 5212.491 & 11 & 473.862 & \multirow{3}{*}{2.90} & \multirow{3}{*}{.000} \\
\hline Within the groups & 9502.594 & 58 & 163.837 & & \\
\hline Total & 14715.086 & 69 & & & \\
\hline
\end{tabular}

The table shows that there is a statistically significant effect for the society's admirable view toward tax evaders on the increase of tax evasion in Jordan at sig. ( $\alpha \geq 0.05)$, where the calculated (F) value was (2.90) and it is higher than the tabulated (F) value at DF of (11/58) which was according to the statistical tables (1.92). Moreover, the researchers have calculated the Practical Significance by calculating eta squared $\left(\mathrm{n}^{2}\right)$ and the effect value (f) which was (0.74), this result according to Cohen criteria is considered as high. The researchers have also calculated the arithmetic means and standard deviations of the items of the domain of the weak prevailing economic situation in Jordan to identify the level of its effect on the increase of tax evasion rates in Jordan. The results were as follows:

Table (25) arithmetic means and standard deviations for the domain of the society's admirable view toward tax evaders

\begin{tabular}{|l|l|l|l|}
\hline Item & $\begin{array}{l}\text { Arithmetic } \\
\text { mean }\end{array}$ & $\begin{array}{l}\text { Standard } \\
\text { deviation }\end{array}$ & $\begin{array}{l}\text { Degree } \\
\text { interpretation }\end{array}$ \\
\hline $\begin{array}{l}\text { The societiy's admiration for tax evaders and considering } \\
\text { their act as a heroic action help to increase tax evasion cases. }\end{array}$ & 3.48 & 1.08 & High \\
\hline $\begin{array}{l}\text { The tax evader's pride of evading tax and the society's } \\
\text { attitude of not criticing such action help to increase tax } \\
\text { evasion cases. }\end{array}$ & 3.68 & 1.01 & High \\
\hline $\begin{array}{l}\text { The society's culture based on encroaching on public fund } \\
\text { increases tax evasion }\end{array}$ & 3.82 & 0.94 & High \\
\hline $\begin{array}{l}\text { The lack of knowledge of the society that tax is one of the } \\
\text { state'srights that has been provided by law and encouraged by } \\
\text { Islam contributes to increase the admiration for tax evaders } \\
\text { and increases tax evasion as a result }\end{array}$ & 3.82 & 0.94 & High \\
\hline Total & 3.70 & 0.98 & High \\
\hline
\end{tabular}


The previous table shows that "The society's culture based on encroaching on public fund increases tax evasion" and "The lack of knowledge of the society that tax is one of the state's rights that has been provided by law and encouraged by Islam contributes to increase the admiration for tax evaders and increases tax evasion as a result" have a high impact on the increase of tax evasion in Jordan for the domain of the society's admiration for tax evaders, as these items had the highest arithmetic mean of (3.82) and a standard deviation of (0.94). The rest of the items had also a high effect on the increase of tax evasion in Jordan with arithmetic means ranging between $(3.48-3.68)$, and a high total as well with an arithmetic mean of (3.70).

Testing the second main hypothesis H02: There is no a statistically significant effect for the social factors at sig. $(\alpha \geq 0.05)$ on the increase of tax evasion in Jordan.

To test this hypothesis and determine the value of the effect resulting from the previously tested factors on the increase of tax evasion in Jordan, the researchers have calculated the arithmetic men as and standard deviations for each domain of the study tool's domains and for the tool as a whole. The results were as follows:

Table (26) the arithmetic means and standard deviations for the domains of the study tool and the tool as a whole $\mathbf{N}=70$

\begin{tabular}{lrrl}
\hline Domain & $\begin{array}{l}\text { Arithmetic } \\
\text { mean }\end{array}$ & Standard deviation & $\begin{array}{l}\text { Result } \\
\text { interpretation }\end{array}$ \\
\hline The lack of the txpayer's loyaty to the state & 4.49 & 0.59 & Very high \\
\hline The unjust of the tax system & 3.95 & 0.79 & High \\
\hline The society's admirable view towards tax evaders & 3.70 & 0.98 & High \\
\hline Tool's total & 4.04 & 0.87 & High \\
\hline
\end{tabular}

From the table we see that the lack of taxpayer's loyalty for the state had the highest arithmetic mean of (4.49) and a standard deviation of (0.59) in affecting the increase of tax evasion in Jordan. We also see that all the mentioned social factors have an impact on the increase of tax evasion in Jordan with estimates ranging between high and very high and with a general high mean.

\section{Results and recommendations:}

The study reached a number of results among which:

1- The lack of corporate governance leads to increase tax evasion and that is has a very high effect.

2. The deterioration of government services and management helps to increase tax evasion cases.

3. There are legal and social factors that help to increase tax evasion cases, such as:

a. The unequality and injustice in the distribution of tax proportions over taxpayers.

b. Unactivated or weak penal system regarding the unadequate fines to deter tax evaders and replace prison sentences with fines.

c. The society's admirable view toward evaders and the society's culture based on encroaching on public fund.

4. The unclarity of law texts and the gaps therein, and the lack of understanding of these tests by the tax department employees help to increase tax evasion.

5. The lack of the citizen's loyalty to the state, represented in the loss of trust in the government and the services it provides to citizens, has increased tax evasion cases.

\section{Recommendations}

The researchers have recommended the following:

1. To review the current legislations, taking into consideration the economic and social situation and investment.

2. To obligate regular commercial companies to follow the corporate governance.

3. To have a lean management in the state's department especially the income tax department.

4. To review the provisions of penal act to suit the sector and the evaded amounts.

5. To issue clear instructions and interpretations attached to laws and regulations simultaneously.

6. To train tax officials on how to detect cases of tax evasion and appropriately motivate them to increase their interest in detecting such cases.

\section{References}

Al-Rawashdeh \& Al-Bawab, Hani \& Atef (2018) "The Effect of corporate Governance Principles in Reducing Tax Evasion in Jordan”, Anbar University Journal for Economic and Administrative Sciences, Anbar University, Iraq. Issue: 129 
Abu Qwek, Kamel Hussein Muhammad (2016), "The Effect of Adherence to the Application of Corporate Governance Principles on the Financial Performance of Companies Listed in PSE" Unpublished PhD Thesis, The World Islamic Sciences and Education University, Amman, Jordan.

Al-Halabi, Muhammad Mahmoud, (2016), "Corporate Governance Tools and their Effect in Reducing Financial Fraud in Jordanian Public Joint Stock Industrial Companies from the Perspective of Certified Public Accountants", Master thesis, Irbid National University.

Al-Rifai \& Al-Najdawi, (2012).

Bani Arshid, Omar, 2017, Tax encyclopedia, general sales tax and income tax.

Al-Omari, Nasiba Muhammad, (2015), "The Effect of Implementing Corporate Governance on Profit Distribution Policies (Comparative Analytical Study between the Financial and Industrial Sectors in Jordan)", Master thesis, Jerash University, Jordan.

Olemat \& Isa, (2016) "The Effect of Implementing the Principles of Corporate Governance on Reducing Tax Evasion in Jordan (A Field Study)", Al-Manara Journal, Vol. 22, Issue (4 / B), 2016.”.

(Abu Nassar, Muhammad, 2019) Tax Accounting, Sales and Income Tax, $3^{\text {rd }}$ edition, Dar Wael for Publishing, P.26.

The amended law of the Income Tax Law No. (38) of 2018, Article (66 item A) and Article (2).

The amended law of the Income Tax Law No. (38) of 2018, article (20).

Temporary Income Tax Law No. (28) of 2009.

Income Tax Law No. (28) of 2009, article (11).

The amended law of the Income Tax Law No. (38) of 2018, article (66). 